\title{
Multinationals, Capital Export, and the Inclusive Development Debate in Developing Countries: The Nigerian Insight
}

\author{
Abel Ezeoha ${ }^{1}$ D $\cdot$ Akinyinka Akinyoade $^{2} \cdot$ Ifediora Amobi $^{3}$. \\ Ogbuagu Ekumankama ${ }^{4}$. Paul Kamau ${ }^{5}$. Agnieszka Kazimierczuk ${ }^{2}$. \\ Catherine Mukoko ${ }^{6}$. Ifeanyi Okoye ${ }^{7} \cdot$ Chibuike Uche $^{2}$
}

Accepted: 21 October 2021 / Published online: 10 January 2022

(c) The Author(s) 2022

\begin{abstract}
In this paper, we employed a blend of multiple and historical case study design, and a mix of institutional, behavioral, resource-based, and multinational theories, to examine the nature of multinational companies' (MNC) engagements in local economic development and capital export practices in an African context. Evidence from our Nigerian case analysis (FrieslandCampina, Nigerian Breweries Plc. and Dangote Cement) confirms the proposition that, faced with a similar degree of uncertainty and constrained institutional environment and laying claims to differing sources of competitive advantage, both local and foreign MNCs would repatriate profits and limit exposures to local value chains (LVCs) mainly as a strategy for mitigating country risks and preserving corporate value. Such limited exposures detach MNCs, especially the foreign ones, from the LVCs, and by doing so push them to deeper reliance on the global value chains (GVCs). Linking local businesses to the GVCs is central in the inclusive development (ID) debate essentially because it allows for the redistribution of economic benefits, helps in building a complementary (rather than competitive) relationship between MNCs and local businesses, and facilitates local businesses' access to international markets. We, therefore, recommend that in pursuit of the inclusive and sustainable development projects in Africa, industrial policies need to be tailored toward stabilizing the policy environment, protecting investments from risk of expropriation, and incentivizing MNCs' participation in the LVCs.
\end{abstract}

Keywords Inclusive development · Capital export · MNCs · FrieslandCampina · Dangote $\cdot$ Heineken $\cdot$ Nigeria

Chibuike Uche

c.uche@ascleiden.nl

Extended author information available on the last page of the article

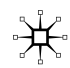




\section{Résumé}

Dans cet article, nous avons utilisé un mélange d'études de cas multiples et historiques, et un mélange de théories institutionnelles, comportementales, basées sur les ressources et multinationales, pour examiner la nature des engagements des entreprises multinationales dans le développement économique local et dans les pratiques d'exportation de capital dans un contexte africain. Les données probantes issues de notre analyse de cas au Nigéria (FrieslandCampina, Nigerian Breweries Plc. et Dangote Cement) confirment la proposition suivante: si les multinationales locales et étrangères étaient confrontées au même degré d'incertitude et à un environnement institutionnel restreint et faisant valoir des sources différentes d'avantage concurrentiel, elles rapatrieraient leurs bénéfices et limiteraient leurs expositions aux chaînes de valeur locales essentiellement pour atténuer les risques liés au pays et pour préserver la valeur de l'entreprise. Ces expositions limitées isolent les multinationales, en particulier les multinationales étrangères, des chaînes de valeur locales et, ce faisant, les poussent à s'appuyer davantage sur les chaînes de valeur mondiales. Le fait de mettre les entreprises locales en lien avec les chaînes de valeur mondiales est un axe qui figure au coeur du débat sur le développement inclusif, essentiellement parce qu'il permet la redistribution des bénéfices économiques, qu'il aide à établir une relation complémentaire (plutôt que concurrentielle) entre les multinationales et les entreprises locales, et qu'il facilite l'accès des entreprises locales aux marchés internationaux. Afin de mettre en place des projets de développement inclusifs et durables en Afrique, nous recommandons que les politiques industrielles soient adaptées afin de rendre l'environnement politique plus stable, de protéger les investissements contre le risque d'expropriation et d'inciter les enterprises multinationales à participer aux chaînes de valeur locales.

\section{Introduction}

The primary aim of this paper is to analyze the contributions of multinational corporations (MNCs) in Africa's Inclusive Development (ID) project, as well as to examine the patterns of MNCs' involvement in capital export practices vis-à-vis profit repatriation. Based on three purposively selected case studies in Nigeria, one of Africa's largest economies, the paper applies both insider-out (the behavioural) and outsider-in (institutional) theoretical lens to make cautious generalization on how institutional weaknesses and the associated high country risks could lead to suboptimal decisions that widen the gap between MNCs and their local business counterparts. The central argument is that prevailing governance and regulatory institutions in most parts of Africa create unstable industrial policy environments that intensify entry barriers into major industries, make access to local raw materials difficult and expensive, render corporate decisions sub-optimal, and incentivize MNCs to export capital in ways that limit their contributions to ID.

Inclusive Development has been defined as a development process that accounts for the marginalization and exclusion of the poor and the vulnerable in the mainstream social, economic and political life of a nation (Hollander et al. 2018; Gupta et al. 2015). In the context of our paper, the ID concept represents the willingness 
and capacity of MNCs to contribute to local economic development by supporting the integration of LVCs into the global value chains (GVCs). The idea is that having local businesses linked to the GVCs encourages backward integration, discourages capital export and induces local productive employment and skills and technology transfer (Dekker et al. 2018). Whereas the LVC model encompasses 'the chain of production and marketing activities that involve a network of interconnected local enterprises that generate domestic value within the chain' (Ngo 2017, p. 8), the GVC model applies when MNCs source their raw materials and semi-finished products more from outside of their host countries (Shimbov et al. 2016). Although this later model is recognized as a potential source of capital export, the inherent potency for skills and technology transfers remains appealing. At the other side of the debate, our paper critiques that an optimal blend of LVCs and GVCs is feasible only in environment where there is strong governance and regulatory institutions that guarantee industrial policy stability with manageable degree of country risks.

Linking local businesses to the GVCs is central in the ID debate essentially because it allows for the redistribution of economic benefits along some multiple levels and multi-dimensional lines (Reinders et al. 2019; Dekker et al. 2018; Hollander et al. 2018). It also helps in building a complementary (rather than competitive) relationship between MNCs and local businesses, while at the same time facilitating the latter's access to international markets (Feyaerts et al. 2020; and Tessmann, 2020), as well as to ensure deeper inclusion of the members of the base/ bottom of the pyramid (Kolk et al. 2014). Using the case of Ivorian Cashew industry, for example, Tessmann (2020) illustrated how local-global linkages could constitute "collective arrangements [that] are crucial for negotiating inter-firm relationships along global value chains'.

An optimal industrial policy choice is one that recognizes the mutual interdependency of LVCs and GVCs as a condition for attaining the ID goals. To account for the indispensable place of local economic actors in the ID equation, for instance, research priorities have recently shifted from the isolated emphasis on attracting foreign investments to drive growth, and to a more inclusive model that enhances the wellbeing of local and grassroots businesses (Kolk et al. 2020; Kolk and Lenfant 2018; Dekker et al. 2018). This new paradigm emerged to smoothen the relationship between MNCs and local businesses that belong to the bottom of the economic pyramid, while at the same time inducing a balanced understanding of the nature and dimensions of MNCs' influence on host countries' institutions.

Within the framework of inclusive development paradigm (IDP), MNCs are expected to show commitments in the local economic value chains and in linking host countries' economies to the international factor markets (Feyaerts et al. 2020). The call for MNCs to be part of the Sustainable Development Goals (SDGs) pursuit has also given more credence to the IDP. The role of MNCs is even more prominent because they occupy an advantage position that accords them greater influence in the international business and policy environment. In Africa specifically, they are dominant in those mineral resource sectors that are the mainstay of most of the economies (OECD 2018). The fact that Africa lags in most indices of development, despite the dominant presence of MNCs in those sectors, raises doubts about the effectiveness of the current models of 
international business engagements in the region. Over the past decades, the engagement models evolved from the post-independence center periphery to the predominant New Development Paradigm (NDP) that emerged to offer an alternative lens for examining the direct roles of MNCs as strategic sources of development finance and improved industrial productivity (Scheyvens et al. 2016). This gave room for a stronger emphasis on attracting foreign investments to induce economic growth, with less practical efforts toward developing indigenous industrial capacities.

The subsequent emergence of the 'Inclusive Development Paradigm' (IDP) was thus to address this shortcoming. From an insider-out perspective, therefore, MNCs are realizing the need to align their visions to the demands of the SDGs, although their performance in this regard has remained less impactful. This is the case in Africa, where the interests of dominant resource- and market-seeking foreign businesses are found to diverge from the development goals of the host economy (Ekumankama et al. 2020; OECD 2018; Carmody 2017; Akinyoade et al. 2016); and where, according to the propositions of the Behavioral theory of the firm, the choices of MNCs are rationalized under institutionally and operationally constrained environments (Cyert and March 1963). In most parts of Africa, for example, Bouchoucha and Benammou (2020) found that the governance systems in place are incapable of incentivizing foreign business' participation in local economic development. In an attempt to mitigate country risks and minimize the hidden costs of businesses occasioned by weak institutions, the managers of MNCs operating in Africa act in ways that are considered sub-optimal and less local value additive. The consequences of this are threefold: (i), MNCs are discouraged from participating in the LVC, (ii) become even more dependent on global networks for intermediate and other productive inputs, and are as such (iii) constrained to making substantial efforts toward skills and technology transfer, (OECD 2018; Giroud and Scott-Kennel 2009).

Furthermore, increased country risk makes the business environment unsafe for capital and profit retention, which in turn increases the rate of capital export (OseiAssibey et al. 2018; Ndikumana 2015). Capital export in this context is narrowly defined as the repatriation of profits from the generating source to overseas investment operations. Although this definition appears narrow, profit repatriation in Africa, according to the 2017 Honest Account ranks second to illicit financial flows as the largest among such sources-accounting for as much as 16 percent of the total outflows (Jubilee Debt Campaign 2017). Regardless of whether they are foreign or locally owned, MNCs are by design likely to be more detached from the LVCs under prevailing conditions of uncertainty and threats of expropriation. The difference in the behaviourial patterns of the MNCs, therefore, shifts from the focus on ownership nationality to the distinctiveness of the underlying resources. It is possible that contrary to popular narrative limiting capital export to foreign MNCs (Curtis and Jones 2017), local MNCs act the same manner to protect themselves from the consequences of country risks. We postulate that, faced with similar degree of uncertainty, both local and foreign MNCs would export capital and limit their exposure to LVCs mainly as a strategy for mitigating country risks and preserving corporate value. Local MNC, in the context of this paper, implies an African-owned firm, 
which in addition to the home country of the owner(s) operates in one or more other countries within or outside the Continent.

By using the Nigerian cases to offer specific empirical clarifications against the inherent biases associated with MNCs' capital export practices, our paper sets the stage for enriching the ID debate in Africa. First, by using case studies from different industries, the paper produces stable evidence to support the claim that the contributions of MNCs to the LVC development (that is, the degree of dependency on local raw materials) are both industry, resource based and ownership sensitive. Firms in less resource-intense industries requiring minimal transportation and transaction costs are likely to depend more on importation to meet their input needs, whereas those that operate in industries with natural protection invest more on backward integration. In the latter, raw materials and intermediates are available and sourced locally, but weak institutions and policy instability make the environment unsafe for profit retention. In terms of ownership, foreign MNCs are likely to be more inclined to investing in industries that require minimal transaction and transportations cost of importation, whereas local MNCs are disposed to invest in those industries with natural and government protections. Whereas western MNCs play with caution to minimize their exposure to expropriation risks, local MNCs act differently by forging political connections with government officials to 'risk aggressive investment in capital intensive industries' (Odijie and Onofua 2020; Akinyoade and Uche 2018). The differences are also explained on the premise that local MNCs build their strongholds on the control of local, non-renewable scarce resources, superior control of natural resources, while foreign MNCs build theirs on knowledge, skills, technology and core competences. Secondly, the tendency to export capital is found to be less sensitive to either resource or ownership specificities. Consistent with earlier evidence (see Ekumankama et al. 2020; Rai et al. 2019; Ndikumana 2015), both foreign and local MNCs are equally likely to adopt capital export as a strategy for protecting their businesses from inherent uncertainties and high risks of expropriation. Thirdly, firms with superior knowledge and technology are likely to contribute more to inclusive development than those with superior claim on natural resources.

To achieve its aims, our paper makes use of a two-stage analytical process involving first a mix of multiple cases (FrieslandCampina, Nigerian Breweries Plc. and Dangote Cement) to examine the extent of MNCs integration into the LVCs in the case of Nigeria; and secondly, regrouping the industries into two classes (with and without natural and government protections; superior resource claim versus superior knowledge and technology claim) to examine the sensitivity of resource and ownership specificities to capital export practices. Jointly examined, the three cases show how the prevailing policy environment in the host country creates opportunities for MNCs to entrench import-dependency as a strategic business choice and any relationship with the LVC as a mark of corporate social responsibility (CSR). The cases of the foreign MNCs (FrieslandCampina and Nigerian Breweries Plc.) compared with that of Dangote Cement, examine whether or not capital export practices are significantly influenced to corporate nationality, and the likelihood of the MNCs contributing to inclusive development. That is, whether contrary to popular claims, local MNCs engage in capital export in the same manner as their foreign counterparts, as well as how the source of competitive edge relates with contribution to 
economic inclusiveness. The rest of the paper is organized as follows: section "Theoretical Framing of Multinationality, Capital Export and ID" reviews the theoretical framing of multinationality, capital export, and ID. Section "Methodology and Analytical Procedure" is on the methodology and section "Case Analysis" focuses on the case analysis and findings. Section "Discussion" discusses the findings and section "Conclusion" concludes the paper.

\section{Theoretical Framing of Multinationality, Capital Export and ID}

The framework of analysis applied in this study is anchored on four inter-related theories. They are the Institutional Theory, the Behavioral Theory of the firm, and the theory of Multinational Corporation and Internationalization. The first stage demonstrates how the strength of governance and regulatory institutions could promote or constrain MNC operations and their commitments to local economic development. The second one shows how managers, acting under bounded rationality, take suboptimal decisions that yield results that conflict with the development needs of the host economies. The third stage of the framework is based on resource-based theory of the firm, which defines how the source of competitive advantage of a firm constitues the major determinant of its contribution to inclusive development, and by extension capital export versus retention. The fourth shows that MNCs' ultimate target on maximizing investment returns and preserving corporate value incentivizes capital export to safer economic climes. A framework linking the three theoretical projections is illustrated in Fig. 1 below.

Figure shows that three principles shape the behavioral tendencies and operating strategies of MNCs in their host economies. They are: the quality of governance institutions, the reactions of the firms to the constraints and/or incentive systems, and the ultimate desire to maximize returns. As indicated and consistent with Kostova et al. (2008), Institutional Theory proposes that the extent to which MNCs aligns their contributions to local development needs is a function of the environmental constraints they face and the decision paths available to deal with such constraints. Following suit, the Behavioral Theory of the Firm underscores the nature

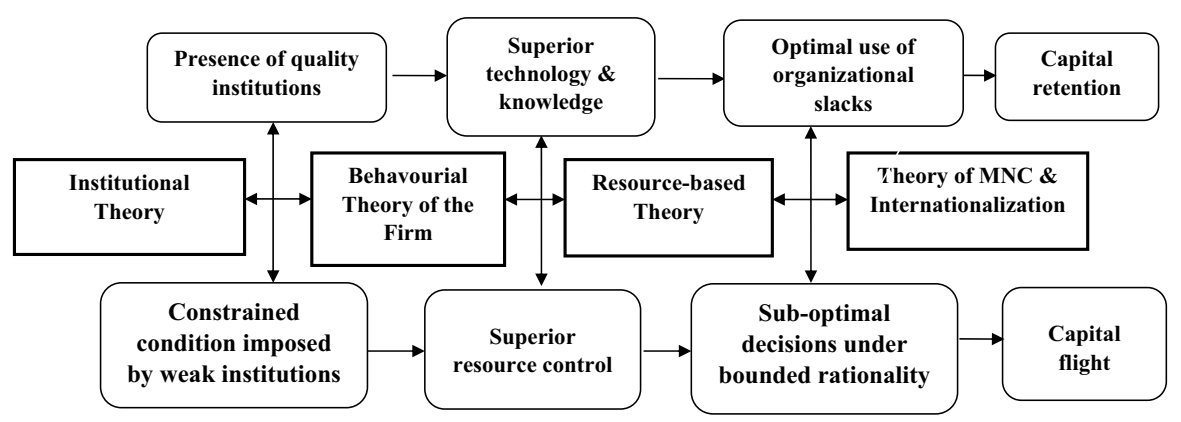

Fig. 1 The theoretical framework of analysis 
and impact of decisions firms make under conditions of incomplete information, conflicting interests of coalition of diverse stakeholders, and macroeconomic uncertainties (Argote and Greve 2007). The Resource-Based Theory proposes that firm's contribution to inclusiveness is dependent on its source of competitive advantage or the type of superior resource claim (see Barney 1991). This links to the Theory of Multinational Corporation and Internationalization that shows how the search for higher returns and quest for global competitiveness constitute the primary reason why MNCs evolve and maintain their presence in certain countries (OECD 2018; Giroud and Scott-Kennel 2009; Lunda 2006).

An interaction of these theoretical standpoints produces two different outcomes. First, the presence of quality governance and regulatory institutions encourages MNCs to effectively build on their core competences and deploy their organizational slacks in ways that reduce conflict of interests, increase innovativeness, and promote capital retention and local economic development. Organizational slack here is defined as the excess capacity (in finance and recourses) uniquely possessed by an MNC (Näslund 1964). Alternatively in the absence of strong institutions, the decisions of MNCs are made under bounded rationality - that is, under high level of uncertainty and incomplete information. This encourages firms to scout for natural protection. It also yields sub-optimal outcomes that incentivize the firms to produce and export capital in manners that challenge the principles of inclusive and sustainable development. From the perspective of the theory of multinational corporations, the commitments of MNCs to LVC development is therefore influenced less by the needs of the host developing countries, and more by the search for higher returns, competitive advantage, and corporate value preservation (Verbeke and Kano 2016).

A number of developing countries have historically attempted to influence the behavior of MNCs toward the promotion of local economic development. This involves policy and regulatory attempts to get MNCs to deploy their core competences for inclusive national development. In Africa, as in a number of other regions, regulatory attempts at getting firms to support local development ideologies constituted the basis for the evolvement of industrial policies such as import substitution industrialization and backward integration (ISI-BI). Empirical evidence, however, reveals that the success of ISI-BI policies is context and industry specific (Mendes et al. 2014). In industries where there is natural protection, transaction and transport costs are too high, and local production is too risky, such policy thrusts are found to discourage foreign investments, and by so doing create room for the emergence of government protected local MNCs. This is especially the case in industries with natural protection where raw materials are locally available in abundance and are too bulky and expensive to import (Akinyoade and Uche 2018). As opposed to their local counterparts, foreign MNCs thrive better in industries with little or no natural protection and where transaction and transportation costs of importation are relatively low.

Notwithstanding the industry specificities, under the IDP lens, the contributions of MNCs are not just valued in terms of the number of their contributions to government tax revenue and GDP growth, but more in their dispositions to the use of local inputs, skills transfer, and productive employment creation (Becker and Fuest 2011). From this perspective, the contributions have been scored 
poorly, with available evidence showing how their operations widen the disparities between the LVCs and the GVCs, as well as exacerbate the dependency on imported factor inputs (Carmody 2017; Curtis and Jones 2017).

The foregoing explains why, since the commencement of the twenty-first century and the emergence of the SDG regime, development efforts at both national and international levels have largely focused on changing the prevailing ideological framing and redirecting policy orientation toward getting MNCs mainstreamed as active agents of local economic development. Not only does the emerging orientation solicit for closer integration of MNCs in local development, it is also designed as a framework for examining the impact of context specificities and local challenges from the perspective of global dynamics. Advocates of the IDP identify the mainstreaming channels to include more commitment to innovative corporate social responsibilities (CSR) (Ramani and Mukherjee 2014) and viable engagement with LVC development (van Tulder and Da Rosa 2014). Between the two channels, the ideological base for the LVC is found to be most appealing, because of abuses inherent in relying mainly on CSR as a measure of the contributions of the MNCs in the SDGs project (Ezeoha et al. 2020; Ramani and Mukherjee 2014).

That many African economies are agricultural and mineral resource-driven also makes the LVC logic more valid. The argument, for instance, is that the development of LVC has higher likelihood of benefiting a larger number of farmers and rural households, and contributing to poverty reduction and food security than the emphasis on high-value GVCs (Fayaerts et al. 2020; Dekker et al. 2018). For the mineral resource sector, the IDP has also been applied to demonstrate how the alignment of MNCs to the ID principles can lead to positive spillover that occurs through the creation of anciliary businesses and skills and technology transfer and the emergence of decent small-scale miners and allied industries along the LVCs (Blomström and Sjöholm 1999). Related to this is the "base/Bottom of the Pyramid" (BOP), which is applied by Kolk et al. (2014) to frame the call for MNCs to get more involved in addressing fundamental development challenges such as poverty and underdevelopment.

In countries where MNCs have sustainably acted to integrate their operations locally, quality institutional governance and viable policies exist as a sine qua non. This, according to Omondi et al. (2017), partly requires having in place: the right infrastructure, local actors with relevant expertise and capacities, functional mechanisms for securing property right and effective government incentive schemes, and a guarantee that MNCs incur minimal transaction costs and are exposed to minimal expropriation risks in their attempts to forge integration within the LVC (Lee et al. 2020; Ekumankama et al. 2020). Among the most popular policy sets are the ISIBI windows. Whereas "backward integration" (BI) describes "the absorption into a firm of some of the tasks carried out by its suppliers (Harrigan 1984; Russo 1992), import substitution industrialization (ISI) relates 'to the development of local substitutes for imported goods' (Ekumankama et al. 2020). Although the two might differ conceptually, their contextual applications are complementary. ISI policies that guarantee backward integration of foreign business operations, for example, have equally ensured that MNCs undertake deeper roles in LVC development; and that 
vertical coordination of MNCs operations benefits local businesses and smallholder farmers (Kolk et al. 2014; Dries et al. 2009; Chagwiza et al. 2016).

Even when correctly framed, it has been shown that the effectiveness of the ISI-BI policies may be challenged by the mode of implementation. In most African countries (and Nigeria in particular), industrial policies are sometimes implemented in manners that contradict the tenets of local industry development. In some instances, the government designs and put across physical and fiscal incentives that make it cheaper and safer for foreign businesses to use local raw materials and labor. In other cases, the atmosphere of implementation is largely hostile and depicts situations where governments go 'to the extent of nationalizing or indigenizing multinational companies all to promote local industrial and economic development' (Cf. Uche 2012; Rood 1976). In such an unstable policy environment, MNCs would generally be selective in their investment decisions, and by so doing limit their investments in capital intensive projects with longer gestations. Where the prevailing policies allow, the choice would be to cling to importation rather than local production.

Our framework of analysis, based on the historical trajectories of capital export depicted by case studies from Nigeria reveals that optimal integration, as postulated, does not manifest automatically, but occurs in stages over time. The framework reveals that the extent to which an MNC contributes to ID can be viewed from the three-stage integration (see Fig. 2 below). The first stage, which shows no evidence of integration with LVCs, is the starting point of most multinational investments in a developing country context. The second stage, termed partial integration, reflects the status of most MNCs operating in the region-where major input factors such as raw materials, work-in-progress inventory, and technology are imported, with only assemblage or product reconstitution taking place locally. The partial integration model is defective in that it only creates limited LVCs. Thus, capital export takes place via transfer pricing, trade mis-invoicing, and profit repatriation. The economic value added of MNC activities are observed mostly through the GDP growth lens

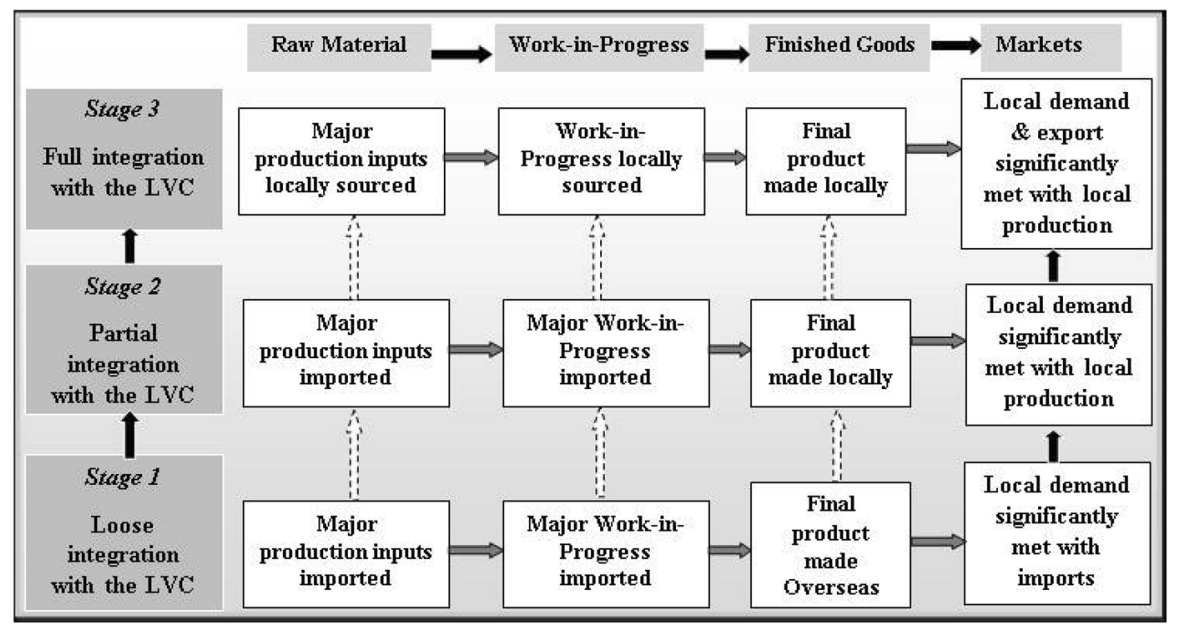

Fig. 2 Stages of MNCs integration in the LVCs 
and not through the microeconomic picture of poverty reduction and inclusiveness (Kolt et al. 2020; Reinders et al. 2019). The third stage is the full integration stage, which involves a situation where firms in an industry source their major input factors and work-in-progress inventories locally, and production is also carried out locally. This stage is considered optimal because of its likelihood to generate greater local value addition.

The extent to which MNC engagements bring about capital export vis-à-vis profit repatriation also varies across the three stages. At the loose integration stage, the rate of capital export is more intense because of MNCs' overly dependency on GVCs. Capital export also takes place at the partial integration stage, but not in the same scale as in the loose integration stage. An optimal level, which is core in the IDP, is the full integration, where the likelihood of capital export is limited and largely through legitimate channels. Capital exports, according to investment literature, are driven by a number of factors, including macroeconomic and policy instability, weak investment protection, corruption, and poor tax administration (Brajcich et al. 2013; Lundan 2006).

From the above framework, the arising development policy question is on the choice of MNC integration that optimally adds value to local economic development. The proponents of the NDP argue that the level of integration in local economic affairs is irrelevant so long as foreign businesses contribute to growth in gross domestic products (Scheyvens et al. 2016). This assumption breaks down given that the extent to which MNCs have contributed to the host country's development and the ID goals remains contentious (Gupta et al. 2015). This is especially so in the light of the rising level of economic marginalization and inequality in most African nations (Reinders et al. 2019; Hollander et al. 2018) — a tendency that is further supported by the existing body of evidence on the prevalent of Resource Curse and Dutch Disease in resource-rich countries in the region.

\section{Methodology and Analytical Procedure}

In order to achieve its primary aim, this paper adopts a blend of multiple and historical case study designs to test the institutional theory that constraints are imposed from outside of the firm; behavioral theory that corporate decisions are made under bounded rationality, resource-based theory that the scarce and non-renewable mature of core resources is a major determinant of firm's contribution to economic inclusiveness, and the theory of multinational corporation and internationalization that whether capital is retained or repatriated is influenced by the ultimate goal to maximize investment returns. The multiple elements of the design allow for external validity of the research approach used, and by so doing give room for a 'nested approach' that allow for analytical generalization (Gibbert et al. 2008; Yin 1994). They are viewed as 'a research strategy for generalizing to a target population of cases from the results of a purposively selected sample of cases' (Greene and David 1984, p. 75). It is also found to be popular in international business studies (e.g., Lin et al. 2019). Unlike single case study whose analysis only focuses on understanding a particular case in depth (Forrest-Larence 2019), the MCS allows us to 
understand the difference or otherwise in the modes of operations of MNCs, and their behavioral tendency toward LVC development. The choice of this design is backed by the fact that analyzing the operational and structural characteristics of MNCs along heterogeneous line helps to improve the generalizability of evidence arising from the analyses of multiple cases. Consistent with the specification of Seawright and Gerring (2008) and Eisenhardt (1989), as well as within the context of our study, a case consists of an MNC and issues around its operations, including among others its operational context, and its reaction to the policy changes. The historical aspect of the design accounts for the different regime of industrial policy in Nigeria under which the MNCs have operated over the past decades. They include the Pre-Indigenization Era (1960-1972), the Indigenization Era (1972-1985), and Post-Indigenization and Liberalization Era (Post 1985). To guarantee internal validatity of the analytical model used, consistent with Gibbert et al. (2008), the three cases are benchmarked over historical timelines allows for the establishment of pattern matching and the use of four related theories provides the platform for a triangulation process that enables the examination of MNCs' engagement in capital export via multiple perspectives.

For the three cases, our units of data collection involve a purposively selected cases made up of FCW Plc. (a subsidiary of Royal FrieslandCampina), Nigerian Breweries Plc. (a subsidiary of Heineken N.V.), as well as Dangote Cement Plc. (a subsidiary of Dangote Group). The choice of these companies stems from the fact that they are all globally acclaimed MNCs - appearing in Forbes lists, which, in line with the prescription by Stewart (2012), helps to validate their choices. That the respective parent companies of the selected MNCs have presence in at least two African countries makes the arising Nigerian evidence relatively generalizable across countries in Africa. The theory of standard operating procedures in Cyertand March (1963), for example, applies prominently in the affairs of MNCs because of the higher possibility of being controlled from the headquarters. Moreover, the process of goal setting and strategy formulation in MNCs is often characterized by topdown schema (Gavetti et al. 2012). In the Nigerian context, each of the firms is the biggest in its industrial sector and the most influential of government policy actions in the sector (see for instance Ezeoha et al. 2020; Akinyoade and Uche 2018).

For each case, we relied mainly on qualitative data mined mostly from secondary sources. As part of our case study protocol, we synthesized evidence from published research articles based on the originating project titled 'Dutch Multinational Businesses, Dutch Government and the Promotion of Productive Employment in Sub-Saharan Africa', which is part of the research agenda of INCLUDE and NWOWOTRO (Reinders et al. 2019). ${ }^{1}$ For the FCW case, the sources of data included, among others, dairy farmers' questionnaire responses comprising of total of 250 local dairy farmers, and a structured interview guide used to collect data from the R\&D/Dairy Development Unit of FCW. For the Heineken and Dangote cases, qualitative data were sourced from seminal articles, relevant documentary information

\footnotetext{
1 The articles in question include: Ekumankama et al. (2020), Ezeoha et al. (2020), Akinyoade and Uche (2018), and Akinyoade et al. (2016).
} 
collected from the corporate websites, annual reports, press releases, print media columnar publications, government policy documents, Nigerian Stock Exchange filings, British National Archives, and other public repositories.

The choice of Nigeria is particularly considered key in enriching literature and enhancing global understanding of the role of MNCs in ID. With a population of over 200 million persons, the country is the largest market in Africa, signaling the fact that MNCs investing therein are primarily market seeking. For each of the cases, Nigeria also constitutes the largest and the most viable market in Africa. Ironically, the level of horizontal and vertical inequalities in the country is also considered among the highest in the world. ${ }^{2}$

In terms of our analytical procedure, we adopted a combination of qualitative exploratory and context analysis research techniques. This approach allowed us to generate evidence on the role of MNCs in local economic development in Africa and to critique their levels of involvements in capital export practices. We propose that regardless of whether an MNC is foreign or local, the current model entrenches monopoly and promotes capital export. As a framework for testing this, we relied on observation/assessment of the series of attempts by the firms toward ID, as well as the consequences there-from.

\section{Case Analysis}

Based on our historical case study design and applying the case study protocol described above, the role and impact of MNCs on ID and LVC development can be analyzed along different policy regimes, origins of which in the case of Nigeria is traceable to the eve of the country's independence in 1960. The regimes, in the context of this paper and consistent with the general classification applied by Adeoye (2005), are categorized according to pre-indigenization, indigenization, and liberalization. As shown in our study, each is underscored by specific characteristics and bears the uncommon distinction as to the degree of alignment of MNCs to inclusive development and involvement in capital exports.

\section{Pre-indigenization Era}

The pre-indigenization period, which was the first stage of the country's conscious efforts at industrial development covered the colonial era up to 1972. During this era, the industrial policies in place were externally driven and designed mainly to serve colonial economic interests (Adeoye 2005). The main business of MNCs operating in Nigeria then was to export raw materials and import finished products. There was little or no form of local industrial integration, and as such MNCs were least inclined to the principles of inclusive development.

\footnotetext{
${ }^{2}$ For a report on this claim and the extreme poverty situation in Nigeria see Adebayo (2018), Nigeria overtakes India in extreme poverty ranking, CNN News, June 26.
} 
Among the three industries studied, the cement industry was the only one with specific attempts at local production - a distinction attributable to the bulky nature of cement production and the efforts of the colonial government to save shipping space both from 'England and the coast-wise' and to preserve needed resources for defence and administration (British National Archives 1942). An earlier invitation to the Associated Portland Cement Manufacturers (APCM) in 1950 'to establish a local cement production plant in the country', for example, failed on the ground that local production made little economic sense (Akinyoade and Uche 2018; Kilby 1975).

At independence, the inability to find willing foreign investors amidst rising local demand for cement forced the government into direct participation in the sector. This resulted in the emergence of the Nigerian Cement Company (Nigercem) in Nkalagu, Eastern Nigeria, in 1957, which was due to the joint efforts of the then the Eastern Regional Government, the Eastern Nigeria Development Corporation, the Danish firm of F.L. Smidth and its British associate (the Tunnel Portland Cement Company) (Ugoh 1964). A consequent bid by APCM to protect its share of the Nigerian market led to the establishment of the West African Portland Cement Company Limited (WAPCO) in Ewekoro in 1960.

Similarly, for the dairy industry, the policy environment was without any form of fiscal intervention to induce local production. Dairy companies incorporated in the country were at liberty to locally produce or import milk and other dairy products. It was also for this reason that FCW already had its popular brand, Peak Milk, dominating the Nigerian market from 1954, even before its entrance into the country in 1973. The same trend was also recorded in the brewery industry where the introduction of imported beer stifled local beer brewing and significantly reduced the consumption of traditional beers (Akinyoade and Uche 2018). This was again made possible by the fact that the colonial government had at that time declined to legalize local beer based on an official excuse that the 'missionary bodies' would oppose the move (Akyeampong 1996). From the 1930s when Heineken first entered Nigeria up to the mid-1940s, the core business of the company remained 'exporting beer through the United Africa Company (UAC) to West Africa' (Akinyoade et al. 2016). The company's later decision to build a local brewery plant in the country in 1946 was motivated by the need to guard against losing its West African market to the Swiss Brewing Society, who at that time had established brewing plants in Accra and Congo to produce Club Beer, respectively, in 1932 and 1935 (Ikime 1999; Van Den Bersselaar 2011). Except for the cement industry, the establishment of the Nigerian plants by FrieslandCampina and Heineken made little impact on the development of the LVCs. This was so because those plants were designed only for the reconstitution and assemblage of imported semi-finished products, and the use of foreign expatriates constituted a common business strategy among the MNCs.

It was the relegation of indigenous businesses that gave rise to the promulgation of the Nigerian Enterprises Promotion Decree (more popularly known as the Indigenization Decree) by the then military government in 1972 to usher in a new regime of industrial policy. Government's plan to use the decree to promote indigenous businesses and moderate the wave of capital export was obvious in the set of primary objectives, which according to the secretary of the implementation process 
include: 'to create opportunities for Nigerian indigenous businessmen; to maximize local retention of profits; and to raise the level of intermediate capital and goods production' (Ogbuagu 1983, p. 241).

\section{The Indigenization Era (1972-1985)}

Although the 1972 indigenization Decree was arguably the boldest policy effort of the post-independence Nigerian government toward internalizing industrial development, it failed in its core mandate of inspiring indigenous participation. The policy framing and implementation rendered it impotent, for instead of indigenizing labor and industrial value chains, its focus was on transferring foreign ownership and capital to Nigerians (Akinyoade and Uche 2018; Uche 2012). Rather than emphasize local content in industrial operations, the implementation turned out to be the starting point for the official mainstreaming of acts of crony capitalism and government patronage in the country's business environment. This manifested in some ways. First, under the supervision of the government, the policy was implemented in ways that allowed foreign enterprises to 'use natives as managers while real control was not relinquished' and the import orientation of the MNCs persisted (Achebe 1989, p. 644). Second, the government facilitated the process by creating a policy atmosphere that allowed pumping public funds into 'parastatals and agencies that were simply used as channels for the redistribution of oil rents to corrupt political elites' (Akinyoade and Uche 2018, p. 8). Another example was the case of the activities of the Presidential Taskforce on import licensing that first instituted by Former President Shagari's Administration in the early 80s. The Taskforce was found to be habitual in issuing 'innumerable licenses to fronts who sold them to importers... who had no need for them while manufacturing plants stood idle' (Achebe 1989, p. 646). The 1977 amended version of the policy ensured further shrinking of foreign ownership interests in the country's corporate sector, but it did little to motivate local production.

Although the three industries involved in our case study were affected by the Indigenization Decree, only NB Plc. was already incorporated and operational in the country before 1972. For FCW, its first Nigerian plant in the capital city of Lagos in 1973 was opened a year after the enactment of the 1972 Decree; and so, the ownership interest of the foreign parent company was restricted to $40 \%$. The company was primarily "incorporated in Nigeria as the West African Milk Company Nigeria Limited (WAMCO) for manufacturing, processing, packing and distribution of various dairy products in the country" (Ekumankama et al. 2020). The implication was that, from the start, the company was indigenous in ownership but foreign in operations.

Inconsistencies surrounding the implementation of the indigenization policy mainstreamed import-dependency and by so doing caused most of the MNCs to detach themselves from the country's LVC. As in the case of cement industry, for example, the rate of import by both government and private organizations was such that resulted to the unpopular Cement Armada Scandal 1974-1980, wherein 'hundreds of cement-laden ships arriving en masse at Lagos, creating severe multiyear-long port congestion during the height of the 1970s oil boom' (Marwah 2020, 
p. 566). The introduction of complementary policies of price control and import licensing in 1974 and 1975 contributed to further relegation of local economic sectors. The fallout was that the MNCs (as in the case of FCW and NB Plc.) had to halt local integration for more lucrative import businesses. Mounting pressure on foreign exchange demand and the crash in international crude oil prices later brought about the abrogation of the indigenization policy and an eventual shift to economic liberalization from 1986.

\section{Post-indigenization and Liberalization Era}

This period provides a comprehensive premise for our comparative case studies. The embodying policy thrust during this period was the adoption of the structural adjustment program (SAP) by the Nigerian government. SAP was designed to cushion the fiscal difficulties faced by the government due to the fall in international crude oil prices. The oil price crisis at that time made it difficult for the country to generate enough foreign exchange to finance its import needs, and even more difficult for manufacturing firms to source factor inputs overseas.

Although SAP championed outward policy orientation with strong support for import liberalization and local currency devaluation (Colman and Okorie 1998, p. 342), businesses were encouraged to embrace ISI-BI strategies (FrieslandCampina Annual Report 2014, p. 19). It was for instance in reaction to the foregoing that FCW for the first time decided to invest in local dairy farming and milk production in the country, an effort that resulted in the establishment of an integrated farm project in Plateau State Nigeria in 1984 (WAMCO Annual Report 1984). Similarly, NB Plc. made attempts at internalizing its operations in Nigeria, through its establishment of an experimental sorghum farm in Niger State Nigeria in 1987. By 1988, the company had announced that 'it had achieved the unprecedented feat of $100 \%$ success with the use of local materials in the brewing Star and Gulder' (Ogunbiyi 2007). In the cement sector, the liberalization policies occasioned by SAP gave room for foreign MNCs to re-enter the cement sector through a series of acquisitions. For example, "Circle (UK) acquired a controlling interest in WAMCO (Ewekoro and Shagamu) where they were pioneer investors. The same Blue Circle, which was later bought by and became part of Lafarge SA, also used the opportunity to acquire controlling shares in Ashaka Cement" (Akinyoade and Uche 2018). The exercise eventually gave Lafarge SA a dominant position in the cement production business in Nigeria.

The initial attempts by MNCs to take advantage of the liberalization policies, however, failed for specific reasons. For FCW, the dairy farm project failed because of location-related challenges, which rendered transportation and transaction costs very expensive. In the case of NB Plc., the failure of its 1987 sorghum farm project was linked to the parent company's lack of background expertise in sorghum farming in its home country, the Netherlands (Akinyoade et al. 2016). For the cement industry, increased foreign interests did not significantly alter the import-dependency 
structure of the industry. As evident in Fig. 3 below, most of the foreign firms, until 2005 became even more incentivized to import rather than produce locally.

Nigeria's industrial policy focus changed radically following the country's return from military to civilian rule in 1999. The newly inaugurated democratic government from 1999 instituted a series of policy measures to promote local production. First, policy incentives were granted to key manufacturing sectors such as cement, textile and automobile in the form of tariff and tax breaks and exemptions, pioneer industry schemes. Quotas and tariff concessions were granted to importers of the affected commodities on the ground of demonstrating a commitment to local production. The second was to facilitate government divestment from existing businesses through a series of privatization exercises. The third was the adoption of BI policy in 2002, which was aimed at deepening local production and broadening the industrial space for local participation. The goal of the policy was to make Nigeria self-sufficient, especially in sectors where the country is endowed with a significant level of comparative advantages.

The policy changes no doubt created local opportunities and incentivized MNCs toward locally integrating their operations. For NB Plc., the ban on imported sorghum remained effective until 2008, and the liberal import policy on malted barley provided the company opportunity to expand its operations in the country. The result was the acquisition of the third largest brewery in the country (Consolidated Breweries Plc.) in 2000, as well as the opening of an ultra-modern brewing plant in the south eastern part of the country in 2003. The latter allowed NB Plc. to commence the production of Heineken Beer in Nigeria-a brand that depends on $100 \%$ imported barley (Akinyoade et al. 2016). It was this push by NB Plc. that led to the Nigerian government's decision in 2003 to reintroduce a total ban on imported beer. Although the company turned its attention to sorghum, a crop that is widely grown in Nigeria, "the effort at backward integration was to later peter out following the policy reversal" (Akinyoade et al. 2016, p. 682; FrieslandCampina Annual Report 2014, p. 19). While relying on the GVC

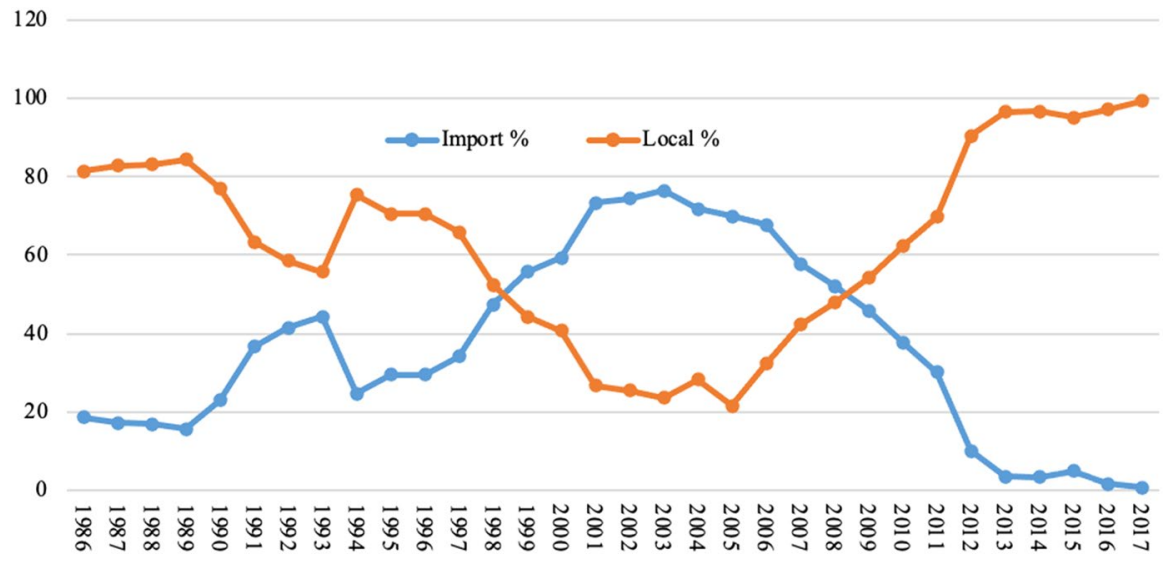

Fig. 3 Cement production statistics Nigeria 1986-2017 


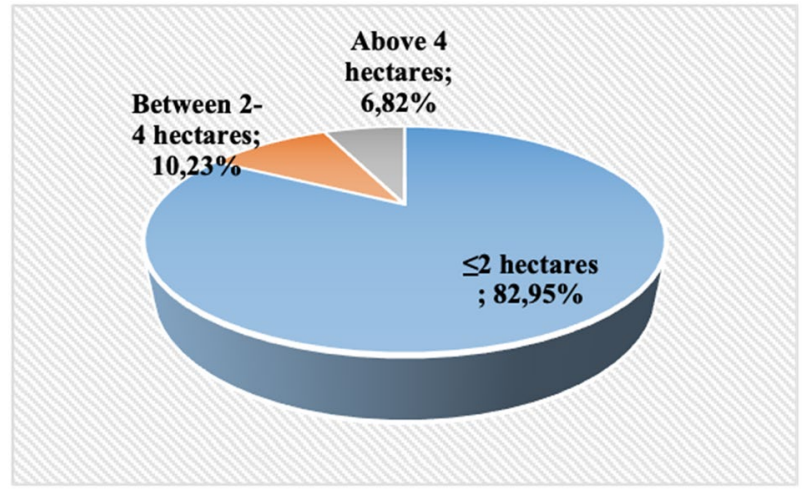

Fig. 4 Percentage of farm holidays. Source Researchers' Field Work, 2016

for its production inputs, NB Plc., however, continued its sorghum farm project, albeit as a mark of corporate social responsibility.

In the case of FCW, a later experiment, through a Dairy Development Program (DDP) and Milk Collection Centres in August 2010 failed to achieve the desired results essentially because it was ill-conceived as a mark of corporate social responsibility rather than a business development model (Ekumankama et al. 2020). For instance, FCW would buy milk from the farmers at a price above prevailing market prices as a way of targeting to "transform the social and economic status of the local farmers' (Ekumankama et al. 2020). The scheme was equally burdened by the fact that the cost of dealing with disaggregated smallholder dairy farmers was high. As shown in Fig. 4, for example, in the backdrop of data analysis from one of the original studies that formed the basis of this paper, of the 88 farmers who responded to the question on the proportion of their farm holdings, about $83 \%$ held just 2 hectares or less, which restricted access to grazing land. Failed attempts at BI by FCW, therefore, left the country largely dependent on imported milk.

For the cement industry, combined policies of ISI-BI in the sector were relaunched by the government to drive and boost local production, cut down importation, and ultimately reduce prices. At the start, the BI component of the new policy regime committed to building cement manufacturing plants in Nigeria as a condition for securing import licenses, as well as granting import duty and VAT waivers for cement production equipment. To this effect, granting of import license was restricted only to importers who show proof of building factories for local cement manufacturing in the country (Egwuatu, 2009). This resulted in the emergence of two new cement plants and the reactivation of the third one between 2002 and 2008. Inability to meet local demand for cement subsequently led to the relaxation of the ISI policy and the lifting of an earlier ban on bulk cement in the latter part of 2008.

Among the three companies studied, the performance of Dangote Cement (and by extension the cement industry in the country) makes the sector an interesting case. Given that investing in local cement production requires long-term gestation and a stable policy environment, firms needed a great deal of government support and assurances to make such investment. Whereas it was easier for local businesses 
to court government and secure the needed protection and incentives for such investments, such was not the case for foreign businesses. The risks of continuing operation in the country were heightened by the growing spread of multilateral antibribery conventions, especially as firms of OECD members countries are expected to adhere strictly to the 'Convention on Combating Bribery of Foreign Public Officials in International Business Transactions 1997'or risk being sanctioned at home. Whereas the foreign cement MNCs were operationally restrained by this Convention, Dangote took full advantage of Nigeria being his home country and the fact that the country was not bound by the OECD Convention.

The influence of Dangote Cement Plc. in the cement industry became prominent from 1999 which was occasioned by the changing industrial structure. It has been claimed that changes in the cement policies during the period were influenced mostly by Aliko Dangote, the owner of Dangote Group and Dangote Cement. Supported by the then Government of Obansajo, Dangote in 2000 and 2002 bidded and acquired Benue Cement Plc. and Obajana Cement Plc., respectively, both in the North Central geopolitical zone of the country. In consideration of its milestone in the industry, Aliko Dangote in 2009 sent a petition to the President on the need to ban cement importation (Egwuatu 2009). At that time, as shown in Fig. 1, Nigeria had attained up to $50 \%$ self-sufficiency in cement production. Although the Dangote Cement case mirrors a case of success in the backward integration policies of African governments (Odijie and Onofua 2020), the effectiveness of the model in enthroning inclusive development and moderating the spate of capital flight remains overwhelmingly doubtful.

Notwithstanding that the institutional structure and policy environment might have prevented MNCs from forging sustainable integration and contributing to local production in the country, there is no evidence to show that the firms suffered financial losses as a result. To date, the gross margin of Heineken (the parent company of NB Plc.) comes from the Nigerian market, which makes the country the second most profitable market after Mexico (Movendi 2020). For the three MNCs studied, the profit levels increased steadily, resulting in the adoption of active dividend policies averaging over $50 \%$. The announcement of the indigenization policy in 1972specifically forced many foreign businesses to adopt active dividend policies in excess of $100 \%$ (Uzoaga and Alozieuwa 1972). This was the case for NB Plc. who paid as much as $102 \%$ and $120 \%$ as dividends in 1972 and 1973. As indicated in Figs. 5, 6, and 7 below, the MNCs rather chose the course of active dividend policies that discourage profit and capital retention as against capital export.

Consistently also, FCW has defended its attachment to GVC on the ground that Nigeria is a risky country to do business; and that its adoption of active dividend policy was a way of limiting the risks (FrieslandCampina Annual Report 2013, 2014). Being attached to the GVC implies that much of the profits are expended buying input factors from overseas parent companies and subsidiaries. This same spirit is also driving the move by Dangote Group's plan to ride on the profits from its cement business to invest up to US\$50 billion in the United States and Europe by 2025 (Bloomberg, January 9, 2020). The fallout of an unstable industrial policy environment is that both foreign and local MNCs strategize to protect themselves by engaging in 'the international transfer of value-added and profits' and minimal 


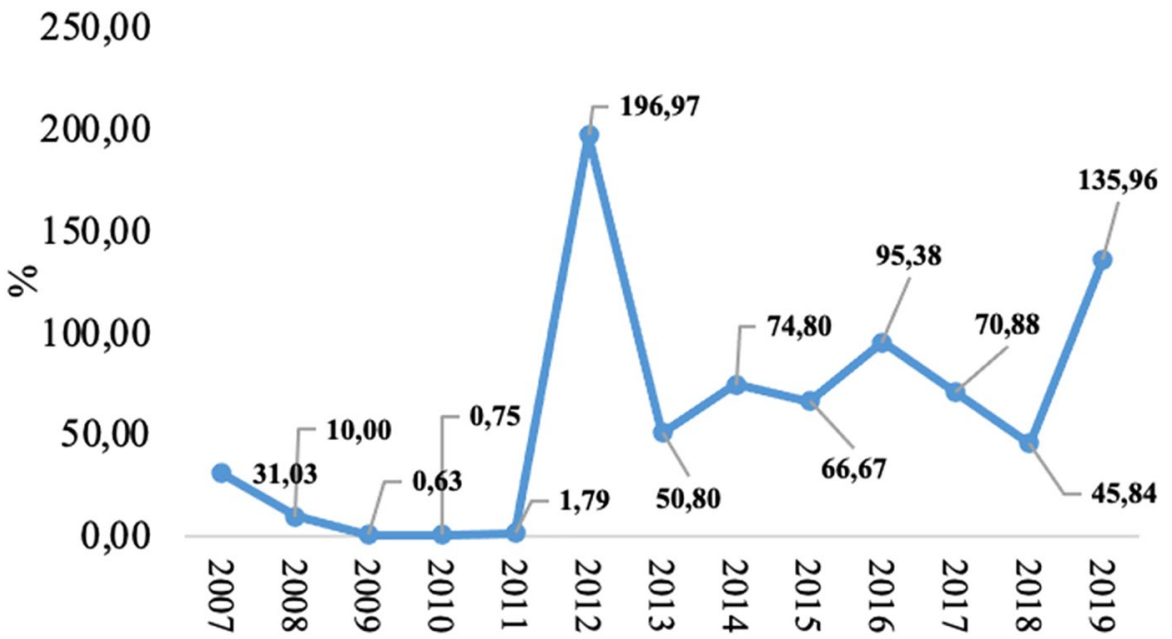

Fig. 5 Dangote cement dividend payout. Source Dangote cement annual reports for various years

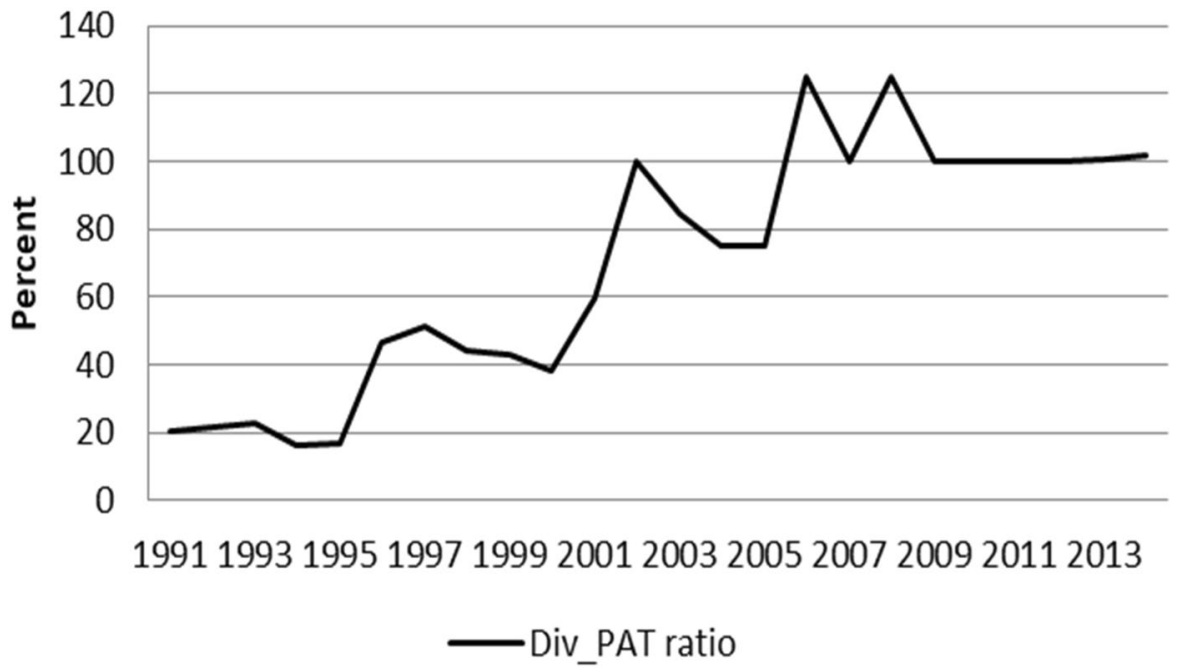

Fig. 6 Trends in FCW Dividend Payout Policy. Source Computed from FCW Annual Reports (Various Issues)

contribution to the local value chain (OECD 2018). This is consistent with the findings reported in Honest Account that up to $16 \%$ of the total capital outflows from Africa derive from legitimate profit repatriation by MNCs (Curtis and Jones 2017). 


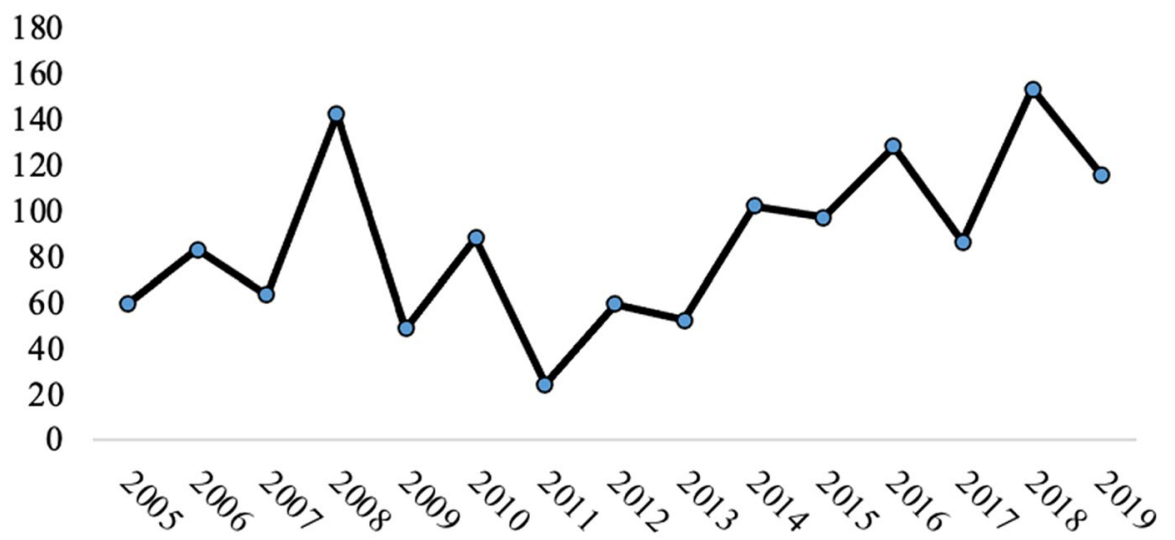

Fig. 7 NB Plc. Percentage of dividend to earnings per share. Source NB Plc. Annual reports for relevant years

\section{Discussion}

This paper primarily analyzed the contributions of MNCs in Africa's Inclusive Development (ID) project, and examined the patterns of MNCs' involvement in capital export practices vis-à-vis profit repatriation. The study makes use of three purposively selected case studies from Nigeria, as well as the theoretical lenses of insider-out (the behavioral) and outsider-in (institutional). The results arising from the study reveal that in an environment where institutional weaknesses, industrial policy instability, and the associated high country risks prevail, MNCs are bound to make sub-optimal decisions that widen the gap between them and their local business counterparts. They are also incentivized to export capital in ways that limit their contributions to local value chain (LVC) and inclusive development (ID). MNCs being detached from the LVCs are found in the case of Nigeria to be sensitive to both the types of industries and the nationality of the MNCs in question. Foreign MNCs have more competitive advantage in less resource-intense industries requiring minimal transportation and transaction import costs are likely to depend more on importation to meet their input needs. Local MNCs are more inclined to industries with natural protection invest more on backward integration. Consistent with the evidence from Odijie and Onofua (2020) and Akinyoade and Uche (2018), the dichotomy here is account for by the fact that each class of firms adopts different strategies to limit its exposure to the uncertainty in the industrial policy environment and the associated expropriation risks.

On the capital export proposition that form part of the primary aim of this paper, the results supports the findings of Ekumankama et al. (2020), Rai et al. (2019), and Ndikumana (2015) that point at both foreign and local MNCs are equally likely to adopt capital export as a strategy for protecting their businesses from inherent uncertainties and high risks of expropriation. By implication, both foreign and local MNCs engage in capital export to preserve corporate value, regardless of whether or not they operate in naturally and government protected industries. 
Consequently, our analysis reveals that deeper attachment to GVC is not because of the multinational status of the firms, but more because of the entry requirements in the industry in question and the very nature of the operating environments in the host developing countries. For multinational companies relying on agricultural inputs, linking MNCs to local farmers is near impossible due to institutional challenges, the absence of organized LVC, and the lack of natural and government protections. The problem created by geographical dispersion of value chain actors, for instance, is exacerbated in areas where the quality of existing institutions and infrastructure is poor. This is the case of FCW having to cope with the local transportation and transaction costs of dealing with disaggregated smallholder dairy farmers; and NB Plc. having to connect its sorghum farming project in Niger State to its manufacturing bases in the Southern part of the country.

Each of the three industries we studied took off at a point where the MNCs were only involved in producing overseas and selling to the host countries through the GVCs. This was particularly the case of FCW and Heineken. During that stage, there was little or no connection between the operations of the MNCs and the local economic system. In the cement industry, that was also the practice before the emergence of the first cement plant in the country in 1956 up to the adoption of SAPinduced liberalization policies of 1986. The absence of any meaningful integration also implied that productive employment and skills transfer were mere policy illusions of the then government.

After several years of its existence in Nigeria, and only until recently (c.f Akinyoade 2020), for example, NB Plc. continually relied on imported sorghum and malted barley to run its nine breweries in the country. For Dangote Cement, much of the gypsum inputs used in the production of cement are sourced from overseas and key technical experts manning the plants are foreigners. Although productive employment and skills transfer take place at the second stage of our model, the degree is not such that can engender sustainable local value chain and by extension inclusive development. In both the first and the second stages, the operations of MNCs instead crowd-out local industrial activities. This is evident in the dairy and brewery industry cases studied, where local farming activities remain crude, disintegrated and largely informal.

In our three-stage analytical model, two of the MNCs studied have over time moved from the loose to the partial integration stage. Among the three case studies, only Dangote Cement appears to have significantly progressed toward full backward integration. Unlike the situation before 2002, local cement needs in the country are currently $98 \%$ locally produced. NB Plc. also appears to have made some significant progress. Despite their importing "a small amount of malt" to improve the sorghum-based beer, NB's raw materials packaging $100 \%$, sorghum $100 \%$, and as Henk Wymenga (former director Lagos) said, water that constitutes $60 \%$ of all production materials are all sourced from within Nigeria. Realistically, their products appear to be meeting Nigeria's beverage self-sufficiency and their products are sold at half the price in Nigeria when compared to the neighboring countries, as far as Ghana.

Notwithstanding the progress made by Dangote cement in advancing cement production toward full integration, the company's engagement as a local multinational has been criticized on some grounds. First is the political connection and 
crony capitalism, which is believed to have accorded the company unfair advantage, which imposes entry barriers and results in unfair cement prices and welfare losses (Ezeoha et al. 2020). Second, due to their closer attachment to GVC, MNCs regardless of being local or foreign engage in capital export. Our study, for instance, reveals that Dangote Cement has as much incentive for capital export as the cases for FCW and NB Plc. The Dangote Cement case has shown that attainment of full integration in institutionally weak environment creates monopoly and fails to curtail capital export. They all have consistently maintained high-profit margin and very active dividend policies in their respective industries; and have uniformly deplored local profits to support overseas operations. This tendency leaves the LVC undeveloped and undermines the public drive for inclusive and sustainable development.

\section{Conclusion and Policy Implications}

The Nigerian case study shows that constrained by institutional weakness and uncertainty in the industrial policy environments, MNCs behave alike in terms of their quest for higher returns (according to the theory of multinational corporate and internationalization) and value preservation. In terms of choice of industry of operation, local MNCs are incentivized to go for industries with natural and government protections, while foreign MNCs prefer industries where the industrial policy is relaxed and the transportation and transaction costs of imports are minimal. Local MNCs are also more likely to draw their competitive strength from laying monopolistic claims on local, non-renewable scarce resources, while foreign MNCs could build their competitive advantage on knowledge, skills, technology, competences. Unlike their foreign counterparts, local MNCs ride on political connections to thrive more in industries that are capital intensive and require longer gestations. The conclusion is also supported by the fact that, apart from Larfage that had to shrink its production capacity from a controlling share of 46 percent in 2002 to a level of less than $25 \%$ by 2015 (Akinyoade et al. 2018), other cement MNCs (such as Heidelberg Cement) had divested from the country since 2008. Weak institutional context and unstable industrial policy environment create opportunities for MNCs to entrench import-dependency as a strategic business choice and to uphold a relationship with the local value chain actors as a mark of corporate social responsibility. In such an environment, policies are implemented in ways that mainstream crony capitalism and give rise to the emergence of local MNCs that promote monopoly and capital export, and by that undermine ID.

From both theoretical and empirical standpoints, MNCs can contribute to ID in two major ways. First is through committed investments in backward integration that targets local value chain addition. The second is by engaging in capital retention (rather than capital export) practices that promotes expansion in local industrial productivity. Local MNCs are found to have performed better in the former, but their commitment in the latter approach is comparatively as low as the case of foreign MNCs.

The outcome of our study, therefore, clears the air on a number of dichotomous claims on the role of MNCs in inclusive development. First, both foreign and local 
multinationals would be inclined to exporting capital abroad in contexts that are unsafe for profit and capital retention. Second, the gap between MNCs and local economic actors widens where attempts at ISI are not properly aligned with policies that support effective LVC development. This was for instance the case of the indigenization policies of the Nigerian government, which though was designed 'to create opportunities for Nigerian indigenous businessmen' and discourage profit repatriation, ended up exacerbating MNCs attachment to import-dependency. Third, our study advances an important course that requires the contributions of MNCs to be measured not by their nationality, but by their being able to broaden the industrial space for local participation. The dichotomous claims collapses given that the decision paths for MNCs that build their competitive advantage on the control of local, non-renewable scarce resources are likely to be uniform; the same way the decision paths could be similar for MNCs whose sources of competitive advantage hinge on skills, knowledge and technology. This, as shown in our study, is regardless of whether an MNC is local or foreign. Considering the above, we recommend that in pursuit of the inclusive and sustainable development projects in African countries that are characterized with weak institutions, industrial policies should be tailored toward stabilizing the policy environment, protecting investments from risk of expropriation, and incentivizing MNCs' participation in the LVCs. Countries can mitigate expropriation risks by subscribing and committing themselves to mutually benefiting bilateral investment treaties that promote access to international arbitration platforms. Other options that have been empirical found to mitigate expropriation and investment risks include: straightening the institutional structures that promote rule of law, property rights protection, and effective land governance. More specifically, regional bodies like African Union and the respective regional economic communities can agree on and design an African/Regional Investment Guarantee Agency modeled to function like the World Bank promoted Multilateral Investment Guarantee Agency (MIGA). The existence of such agency will no doubt help to enhance MNCs' confidence, especially in terms of increasing capital inflows and retention.

Acknowledgements The original research leading to this article emanate from a wider project on increasing the value of Dutch multinationals for national economies: a comparative study of Kenya and Nigeria. The project is part of the research agenda of the Knowledge Platform on Inclusive Development Policies-NWO-WOTRO (2014-2017). The generous funding of the project by the Dutch Ministry of Foreign Affairs is acknowledged.

Open Access This article is licensed under a Creative Commons Attribution 4.0 International License, which permits use, sharing, adaptation, distribution and reproduction in any medium or format, as long as you give appropriate credit to the original author(s) and the source, provide a link to the Creative Commons licence, and indicate if changes were made. The images or other third party material in this article are included in the article's Creative Commons licence, unless indicated otherwise in a credit line to the material. If material is not included in the article's Creative Commons licence and your intended use is not permitted by statutory regulation or exceeds the permitted use, you will need to obtain permission directly from the copyright holder. To view a copy of this licence, visit http://creativecommons.org/licen ses/by/4.0/. 


\section{References}

Achebe, I. 1989. The legal problems of indigenization in Nigeria: A lesson for developing countries. Hastings International and Comparative Law Review 12 (3): 637-677.

Adeoye, B.W. 2005. Industrial development in Nigeria in the context of globalization. Nigerian Institute of Social and Economic Research (NISER), Ibadan.

Adebayo, B. 2018. Nigeria Overtakes India in Extreme Poverty Ranking, CNN News. https://edition.cnn. com/2018/06/26/africa/nigeria-overtakes-india-extreme-poverty-intl/index.html

Akinyoade, A., and C. Uche. 2018. Development built on crony capitalism? The case of Dangote Cement. Business History 60 (6): 833-858.

Akinyoade, A., O. Ekumankama, and C. Uche. 2016. The use of local raw materials in beer brewing: Heineken in Nigeria. Journal of the Institute of Brewing 122 (4): 682-692.

Akinyoade, A., A.H. Kazimierczuk, O. Agbaje T. Ekumankama, and A.J. Dietz. 2020. Sorghum value chain in Nigeria. Explorative study. Research Report ASCL \& Heineken. https://www.ascleiden.nl/ news/sorghum-value-chain-nigeria-explorative-study

Akyeampong, E. 1996. What's in a drink? Class struggle, popular culture, and the politics of akpeteshie (local gin) in Ghana, 1930-1967. Journal of African History 37: 215-236.

Argote, L., and H.R. Greve. 2007. A behavioral theory of the firm-40 years and counting: Introduction and impact. Organization Science 18 (3): 337-349.

Barney, J. 1991. Firm resources and sustained competitive advantage. Journal of Management 17 (1): 99-120.

Becker, J., and C. Fuest. 2011. The taxation of foreign profits-The old view, the new view and a pragmatic view. Intereconomics 46 (2): 92-97.

Blomström, M., and F. Sjöholm. 1999. Technology transfer and spillovers: Does local participation with multinationals matter? European Economic Review 43 (4-6): 915-923.

Bouchoucha, N., and S. Benammou. 2020. Does institutional quality matter foreign direct investment? Evidence from African countries. Journal of the Knowledge Economy 11 (1): 390-404.

Brajcich, A.M., D.L. Friesner, and M.Q. McPherson. 2013. Key determinants of repatriated earnings by US multinational enterprises. Multinational Business Review 21 (3): 269-289.

British National Archives Kew, Extract from letter to Brigadier Bishop from Lord Swinton dated 31 July 1942 (BNA CO 852/371/6)

Carmody, P. 2017. The new scramble for Africa. Hoboken: Wiley.

Chagwiza, C., R. Muradian, and R. Ruben. 2016. Cooperative membership and dairy performance among smallholders in Ethiopia. Food Policy 59: 165-173.

Colman, D., and A. Okorie. 1998. The effect of structural adjustment on the Nigerian agricultural export sector. Journal of International Development: THe Journal of the Development Studies Association $10(3): 341-355$.

Curtis, M., and T. Jones. 2017. How the world profits from Africa's wealth, Honest Accounts 2017, June 6

Cyert, R.M., and J.G. March. 1963. A behavioral theory of the firm, 169-187. Englewood Cliffs: Prentice-Hall.

Dekker, M., W. Simbanegavi, S. Hollander, and O. Miroro. 2018. Boosting productive employment in Africa: What works and why. Synthesis report series. INCLUDE. http://includeplatform.net/downl oads/synthesis-productive-employment.

Dries, L., E. Germenji, N. Noev, and J.F.M. Swinnen. 2009. Farmers, vertical coordination, and the restructuring of dairy supply chains in Central and Eastern Europe. World Development 37 (11): 1742-1758.

Egwuatu, P. 2009. CMAN demands implementation of 2002 backward integration policy for cement, vanguard/all Africa Global Media via COMTEX, 13 July

Ekumankama, O., A. Ezeoha, and C. Uche. 2020. The role of multinational corporations in local dairy value chain development: Case of Friesland Campina WAMCO (FCW) in Nigeria. International Food and Agribusiness Management Review 23: 55-70.

Eisenhardt, K.M. 1989. Building theories from case study research. Academy of Management Review 14 (4): 532-550.

Ezeoha, A., C. Uche, and A. Ujunwa. 2020. Crossing the borderline in strategic corporate philanthropy: Dangote and the construction of cement roads in Nigeria. Business Ethics: A European Review 29 (1): 70-81. 
Feyaerts, H., G. Van den Broeck, and M. Maertens. 2020. Global and local food value chains in Africa: A review. Agricultural Economics 51 (1): 143-157.

Forretst-Lawrence, P. 2019. Case study research. In Handbook of research methods in health social sciences, ed. P. Liamputtong, 317-331. Singapore: Springer.

FrieslandCampina. 2013. Annual Report 2013. Royal FrieslandCampina. https://www.frieslandcampina. com.ng/app/uploads/2015/07/FrieslandCampina-WAMCO-2013-Annual-Report.pdf

FrieslandCampina. 2014. Annual Report 2014. Royal FrieslandCampina. https://www.frieslandcampina. com/uploads/2020/03/FrieslandCampina-Annual-Report-2014.pdf

Gavetti, G., H. Greve, D. Levinthall, and W. Ocasio. 2012. The behavioral theory of the firm. The Academy of Management Annals 6 (1): 1-40.

Gibbert, M., W. Ruigrok, and B. Wicki. 2008. What passes as a rigorous case study? Strategic Management Journal 29 (13): 1465-1474.

Giroud, A., and J. Scott-Kennel. 2009. MNE linkages in international business: A framework for analysis. International Business Review 18 (6): 555-566.

Greene, D., and J.L. David. 1984. A research design for generalizing from multiple case studies. Evaluation and Program Planning 7 (1): 73-85.

Gupta, J., N.R. Pouw, and M.A. Ross-Tonen. 2015. Towards an elaborated theory of inclusive development. The European Journal of Development Research 27: 541-559.

Harrigan, K. 1984. Formulating vertical integration strategies. Academy of Management Review 9: $638-652$.

Hollander, S., M. Dekker, O. Miroro, F. van Kesteren, J. Bossuyt, and M. de Tollenaere. 2018. Strategic actors for inclusive development in Africa. Synthetic report series.

Ikime, O. 1999. Fifty years of brewing excellence: A history of Nigerian Breweries Plc. 1946-1996. Lagos: Nigerian Breweries Plc.

Jubilee Debt Campaign. 2017. Honest Accounts 2017: How the world profits from Africa's wealth, May 25

Kilby, Peter. 1975. Manufacturing in colonial Africa. In Colonialism in Africa 1870-1960, the economics of colonialism, ed. P. Duignan and L. Gann, 470-520. Cambridge: Cambridge University Press.

Kolk, A., A. Kourula, N. Pisani, and M. Westermann-Behaylo. 2020. The state of international business, corporate social responsibility and development: Key insights and an application to practice. In Business and development studies: Issues and perspectives, ed. P. Lund-thomsen, M.W. Hansen, and A. Lindgreen. London: Routledge.

Kolk, A., and F. Lenfant. 2018. Responsible business under adverse conditions: Dilemmas regarding company contributions to local development. Business Strategy and Development 1 (1): 8-16. https://doi.org/10.1002/bsd2.5.

Kolk, A., M. Rivera-Santos, and C. Rufín. 2014. Reviewing a decade of research on the "base/bottom of the pyramid" (BOP) concept. Business \& Society 53 (3): 338-377.

Kostova, T., K. Roth, and M.T. Dacin. 2008. Institutional theory in the study of multinational corporations: A critique and new directions. Academy of Management Review 33 (4): 994-1006.

Lee, J.Y., A. Jiménez, Y.S. Yang, and Y. Song. 2020. Political risk, internal versus global value chain knowledge, and subsidiary operational integration. Global Strategy Journal 10 (3): 444-472.

Lin, R., Y. Gui, Z. Xie, and L. Liu. 2019. Green governance and international business strategies of emerging economies' multinational enterprises: A multiple-case study of Chinese firms in pollution-intensive industries. Sustainability 11 (4): 1013.

Lundan, S.M. 2006. Reinvested earnings as a component of FDI: An analytical review of the determinants of reinvestment. Transnational Corporations 15 (3): 33-64.

Marwah, H. 2020. Untangling government, market, and investment failure during the Nigerian oil boom: The Cement Armada scandal 1974-1980. Business History 62 (4): 566-587.

Mendes, A.P.F., M.A. Bertella, and R.F. Teixeira. 2014. Industrialization in Sub-Saharan Africa and import substitution policy. Brazilian Journal of Political Economy 34 (1): 120-138.

Movendi International. 2020. Nigeria: Heineken Pushes Further for Beer Market Domination, Policy News. https://movendi.ngo/news/2020/09/11/nigeria-heineken-pushes-further-for-beer-marketdomination/.

Näslund, B. 1964. Organizational slack. EkonomiskTidskrift, 66 (1): 26-31.

Ndikumana, L. 2015. Integrated yet marginalized: Implications of globalization for African development. African Studies Review 58 (2): 7-28.

Ngo, C.N. 2017. Local value chain development in Vietnam: Motorcycles, technical learning and rents management. Journal of Contemporary Asia 47 (1): 1-26. 
Odijie, M.E. 2020. Is traditional industrial policy defunct? Evidence from the Nigerian cement industry. Review of International Political Economy 27 (3): 686-708.

OECD. 2018. Multinational enterprises in the global economy: heavily debated but hardly measured. Policy Note. https://www.oecd.org/industry/ind/MNEs-inthe-global-economy-policy-note.pdf.

Ogbuagu, C.S. 1983. The Nigerian Indigenization Policy: Nationalism or Pragmatism? African Affairs (pp. 241-266).

Ogunbiyi, Y. 2007. 60 Years of winning with Nigeria: The history of Nigerian Breweries PLC. Lagos: Nigerian Breweries PLC.

Omondi, I., E.J. Rao, A.A. Karimov, and I. Baltenweck. 2017. Processor linkages and farm household productivity: Evidence from dairy hubs in East Africa. Agribusiness 33 (4): 586-599.

Osei-Assibey, E., K.O. Domfeh, and M. Danquah. 2018. Corruption, institutions and capital flight: Evidence from Sub-Saharan Africa. Journal of Economic Studies 45 (1): 59-76.

Rai, S.M., B.D. Brown, and K.N. Ruwanpura. 2019. SDG 8: Decent work and economic growth-A gendered analysis. World Development 113: 368-380.

Ramani, S.V., and V. Mukherjee. 2014. Can breakthrough innovations serve the poor (bop) and create reputational (CSR) value? Indian Case Studies. Technovation 34 (5-6): 295-305.

Reinders, S., M. Dekker, F. van Kesteren, and L. Oudenhuijsen. 2019. Inclusive development in Africa. Synthesis report series. Knowledge platform on inclusive development policies, March. Trois niv

Rood, L. 1976. Nationalization and indigenization in Africa. Journal of Modern African Studies 14: $427-447$.

Russo, M. 1992. Power plays: Regulation, diversification, and backward integration in the electric utility industry. Strategic Management Journal 13: 13-27.

Seawright, J., and J. Gerring. 2008. Case selection techniques in case study research. Political Research Quarterly 61 (2): 294-308.

Scheyvens, R., G. Banks, and E. Hughes. 2016. The private sector and the SDGs: The need to move beyond 'business as usual.' Sustainable Development 24 (6): 371-382.

Shimbov, B., M. Alguacil, and C. Suarez. 2016. International production networks and economic growth: The case of the Western Balkan Countries. Eastern European Economics 54 (1): 49-70.

Stewart, J. 2012. Multiple-case study methods in governance-related research. Public Management Review 14 (1): 67-82.

Tessmann, J. 2020. Global value chains and policy practice: The making of linkages in the Ivorian cashew industry. Competition \& Change 24 (1): 26-43.

Uche, C.U. 2012. British government, British businesses, and the indigenization exercise in post-independence Nigeria. Business History Review 86: 745-771.

Ugoh, S.U. 1964. The Nigerian cement company. Nigerian Journal of Economic and Social Studies 6: 72-91.

Uzoaga, W., and J. Alozieuwa. 1972. Dividend policy in an era of indigenization. Nigerian Journal of Economic and Social Studies 16: 46-478.

Van Den Bersselaar, D. 2011. Who belongs to the 'Star people'? Negotiating beer and gin advertisements in West Africa. Journal of African History 52: 385-408.

van Tulder, R., and A. Da Rosa. 2014. Multinationals and Small-and Medium-Sized Enterprises (SMEs): A linkages perspective on inclusive development strategies. International Business and Sustainable Development 8: 203-227.

Verbeke, A., and L. Kano. 2016. An internalization theory perspective on the global and regional strategies of multinational enterprises. Journal of World Business 51 (1): 83-92.

WAMCO. 1984. Annual Report and Financial Statement. Lagos: West Africa Milk Company.

Yin, R.K. 1994. Case study research: Design and methods, 2d ed. Thousand Oaks, CA: Sage.

Publisher's Note Springer Nature remains neutral with regard to jurisdictional claims in published maps and institutional affiliations. 


\section{Authors and Affiliations}

\section{Abel Ezeoha ${ }^{1} \mathbb{D} \cdot$ Akinyinka Akinyoade $^{2} \cdot$ Ifediora Amobi $^{3}$. Ogbuagu Ekumankama ${ }^{4}$. Paul Kamau ${ }^{5}$. Agnieszka Kazimierczuk ${ }^{2}$. Catherine Mukoko ${ }^{6} \cdot$ Ifeanyi Okoye $^{7} \cdot$ Chibuike Uche $^{2}$}

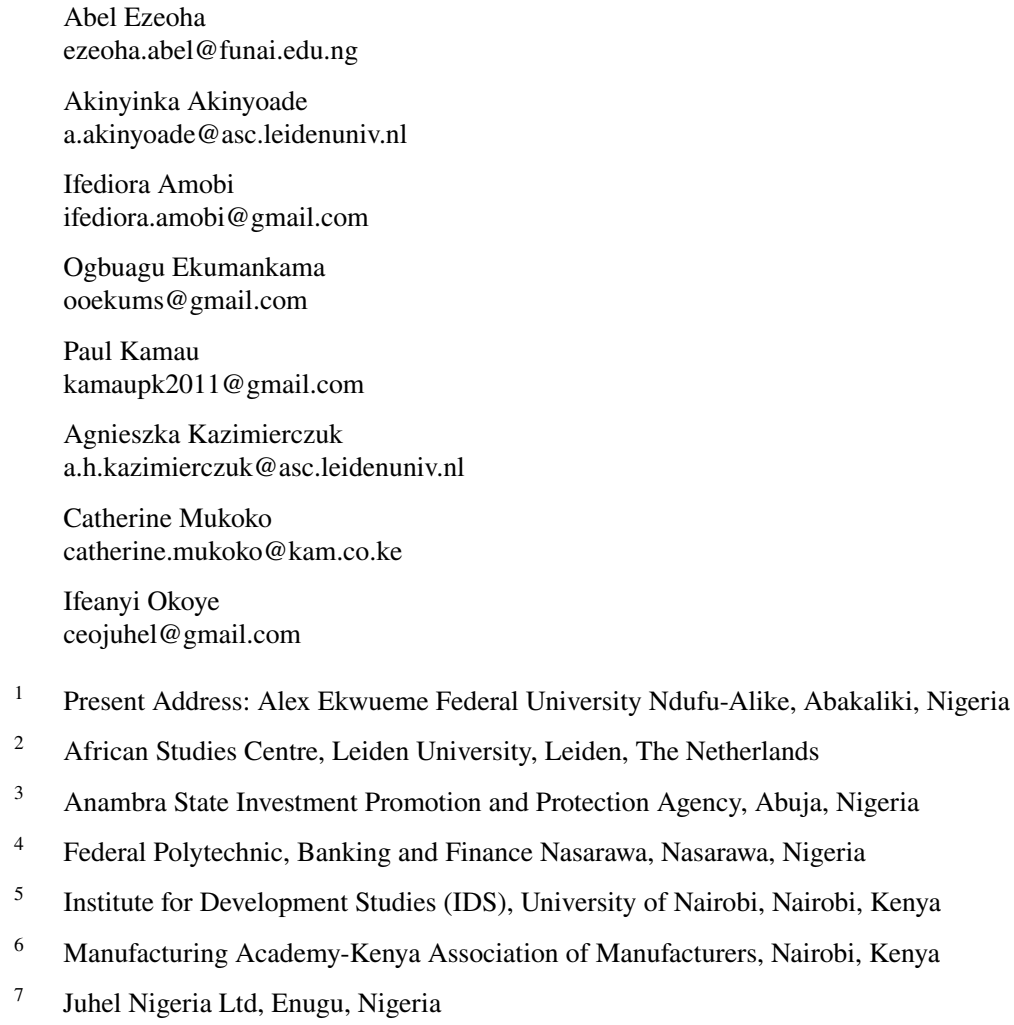

